\title{
Physical and Chemical Properties of Chicken Nugget Combined with Meat of Golden Snail
}

\author{
Yunus Syafie ${ }^{1, *}$, Nurdiyanawati Djumadil $^{2}$ \\ ${ }^{1}$ Department of Animal Husbandary, Faculty of Agriculture, Khairun University, Ternate,Indonesia \\ ${ }^{2}$ Department of Agribusines, Faculty of Agriculture, Khairun University, Ternate, Indonesia \\ ${ }^{*}$ Corresponden Author, e-mail: syafie_unu@yahoo.co.id
}

\begin{abstract}
Golden snail is the major pest in thewet paddy land in the East Halmahera region. The use of chemical pesticides has failed to control the pest and hascaused an increase in environmental pollution. In order to reduce the detrimental effect of the golden snail attack on paddy growth and production, the animal was controlled by using a collection method and can potentially be used as the source of protein in the human diet due to its high nutrition content. This study aimed at examining whether nugget made from a combination of chicken meat and golden snail meat contained high protein and how the performance and taste of the meat combination was. A laboratory experiment was established in a randomized completely design with five treatments: $\mathrm{P}_{0}(100 \%$ chicken meat $) ; \mathrm{P}_{1} 75 \%$ chicken meat $+25 \%$ golden snail meat $) ; \mathrm{P}_{2} 50 \%$ chicken meat + $50 \%$ golden snail meat); $\mathrm{P}_{3} 25 \%$ chicken meat $+75 \%$ golden snail meat); and $\mathrm{P}_{4}(100 \%$ golden snail meat). The treatments were set up in three replications. The variables observed were protein and fat content from each treatment as well as color, taste, texture and smell of nugget made from each treatment. An analysis of variance (ANOVA) was used for determining statistical differences among the treatments. The results showed that nugget with a $100 \%$ chicken meat andwith the addition of up to $50 \%$ of golden snail meat into chicken meat treatments had a good performance in color, texture and flavor. Meanwhile, a higher content of protein was found in a nugget from the treatment with a $100 \%$ chicken meat (15.19\% protein); and with the addition of $25 \%$ ( $15.40 \%$ protein) and $75 \%$ of golden nail meat (15.00\% protein) than other treatments, respectively. In addition, the highest content of fat was found in nugget with the addition of $50 \%$ of golden snail meat treatment (1.79\% fat). It is recommended to add up to $25 \%$ of golden snail meat into the chicken as it still meets the Indonesian National Standard for nugget.
\end{abstract}

Keywords: chicken nugget, golden snail meat, physical and chemical properties

\section{INTRODUCTION}

Golden snail is the major pest that attacks rice plants in the wet paddy land of East Halmahera Regency. The use of chemical pesticideshas failed to control this pest and resulted in a number of environmental problems, including water and soil pollutions. A method that is considered effective to control the growth of the golden snail population is by manually collecting the snails (mechanical method). The collected golden snails would then be processed as food for people, considering the meat contains high nutritions. In 100 grams of fresh golden snail meat, there are $82,37 \%$ of water, $8,69 \%$ of protein, $0,78 \%$ of fat, $1,47 \%$ of ash, and $6,68 \%$ of fiber. Therefore, it is possible to make a nugget product out of golden snail meat.

Nugget is one of the meat-based processed foods. According to [1], the nugget is a form of a groundmeat product that is seasoned, covered in flour batter, breaded, half-cooked(fried), and then frozen for preservation. The making process of nugget requires an emulsifying agent for the stability of the batter. The emulsifying agent in the batter is a protein that binds fat and water as an emulsion. The use golden snail meat as nugget is expected to provide supplementary values to people, especially those living in the North Maluku regency. Therefore, the golden snail can be used for various forms of processed food and increase the popularity of the meat in market.

This research is aimed to find out the combination of chicken and golden snail meats (pomaceacanaliculata), specifically on the protein and fat contents, as well as the level of preference in the nugget product using this meat.

\section{METHODS}

This research had been conducted for three months in the Laboratory of Animal Husbandary, Faculty of Agriculture, Universitas Khairun, Ternate. The examination of protein and fat contents was conducted at the Laboratory of Food Chemistry and Nutrition at IPB Bogor - Department of Food Science and Technology. 
The types of equipment used in this research included food processor, freezer, stove, frying and steaming utensils, scale, aluminum baking tray, stirring spoons, mould, cutting board, heat resistant plastic, stopwatch, and equipment for examining the level of protein and fat. The ingredients used included golden snail meat, chicken meat, bread, skim milk, breadcrumb, egg, frying oil, and seasonings, such as salt, sugar, garlic, shallot, pepper, ice, and mineral water.

This research used the Completely Randomized Design methodology, which involved 5 treatments and 3 replications: P0 : $100 \%$ of chicken meat and $0 \%$ of golden snail meat; P1: $75 \%$ of chicken meat and $25 \%$ of golden snail meat; P2: $50 \%$ of chicken meat and $50 \%$ of golden snail meat; P3: $25 \%$ of chicken meat and $75 \%$ of golden snail meat; P4: $0 \%$ of chicken meat; and $75 \%$ of golden snail meat.

The making process of nugget started withcleaning the golden snail from it's shell. This was intended to obtain the desired meat. The golden snails used were the ones taken directy from the paddy field inEkor sub-district, in East Halmahera Regency. Clean golden snailswere then soaked in water overnightto further cleaned the snails and removed all the remaining dirts that were not washed away during the first cleaning process. Thistreatmentis regulargy done by people who actively consume golden snail meat. Mentioned that in preparing snail as food, it is best to soak the meat beforehand. Aside for completely cleaning the snail, this treatment will also stop the digestive system of the snail from working.

The golden snail which had been soaked overnight were then cleaned in running water. The next step was boiling the snail to ease the process of separating the meat from the shell [3]. After 20 minutes of boiling, the meatswere then separated from the shell using toothpicks.

\section{Research Variables}

The variablesobserved in this research were chemical and physical examinations includingprotein and fat content, and the most favored color, aroma, taste and texture of the nugget.

\section{Data Analysis}

The data were statisticallyanalysed using Analysis of Variance (ANOVA). If there were any difference found between each treatment, further examination would be conducted using the Smallest Real Difference (SRD) test in the level of $5 \%$ and $1 \%[4]$

\section{RESULTS AND DISCUSSION}

\section{Color}

The statistical analysis result of the average grade of the nugget color preference level was presented in Table 1.Based on the results of the average grade (Table 1) above, it shows that there was a variation of preference in each golden snail combination. Therefore the level of preference varies. The average grade on P0 treatment
$(5,33)$ was higher than on $\mathrm{P} 1, \mathrm{P} 2, \mathrm{P} 3$, and $\mathrm{P} 4$. This was mainly due to the fact that the characteristic of golden snail meat is brownish white with black dots, which affected the variation results of responses regarding the color preference.

Table 1. The average grade of nugget color preference level test

\begin{tabular}{|c|c|c|c|c|c|c|}
\hline \multirow{2}{*}{ Repetition } & \multicolumn{5}{|c|}{ Treatment } & \multirow{2}{*}{ Total } \\
\hline & $\mathbf{P}_{0}$ & $\mathbf{P}_{1}$ & $\mathbf{P}_{2}$ & $\mathbf{P}_{3}$ & $\mathbf{P}_{4}$ & \\
\hline 1 & 5,13 & 4,27 & 4,40 & 4,07 & 3,00 & 20,87 \\
\hline 2 & 5,40 & 5,20 & 5,13 & 4,67 & 4,00 & 24,40 \\
\hline 3 & 5,47 & 5,13 & 5,07 & 4,67 & 4,13 & 24,47 \\
\hline Total & 16,00 & 14,60 & 14.60 & 13,41 & 11,13 & 69,74 \\
\hline Average & $5,33^{a}$ & $4,87^{b}$ & $4.87^{b}$ & $4,47^{\mathrm{c}}$ & $3,71^{d}$ & \\
\hline
\end{tabular}

Based on the analysis of variance, the combination of snail meat in each treatment $(\mathrm{P}<0,05)$ directly impacted the color of the nugget. Further SRD test shows that each treatment has a different color. It is because P0 contains $100 \%$ chicken meat, while starting from $\mathrm{P} 1$, the golden snail meat has already been added to the chicken meat. P1 consists of $75 \%$ chicken meat and $25 \%$ golden snail meat, P2 has each $50 \%$ of chicken meat and golden snail meal, P3 consists of $25 \%$ chicken meat and $75 \%$ golden snail meat, while P4 is $100 \%$ of golden snail meat. The rate of color preference that is most favorable by panelists shows on P0 treatment. The color of most treatment differs. P1 and $\mathrm{P} 2$ are similar, while $\mathrm{P} 3$ and $\mathrm{P} 4$ has different results.

\section{Flavor}

The average gradeforthepreferenceof flavor in each combination can be seen in Table 2 .

Table 2. Average grade of the nugget flavor preference

\begin{tabular}{|c|c|c|c|c|c|c|}
\hline \multirow{2}{*}{ Repetition } & \multicolumn{5}{|c|}{ Treatment } & \multirow{2}{*}{ Total } \\
\hline & $\mathbf{P}_{0}$ & $\mathbf{P}_{1}$ & $\mathbf{P}_{2}$ & $\mathbf{P}_{3}$ & $\mathbf{P}_{4}$ & \\
\hline 1 & 5,13 & 4,60 & 4,53 & 4,20 & 4,27 & 22,73 \\
\hline 2 & 5,13 & 4,80 & 4,67 & 4,47 & 4,47 & 23,54 \\
\hline 3 & 4,80 & 4,53 & 4,67 & 4,93 & 4,47 & 23,40 \\
\hline Total & 15,06 & 13,93 & 13,87 & 13,60 & 13,21 & 69,67 \\
\hline Average & $5,02^{a}$ & $4,64^{b}$ & $4,62^{b c}$ & $4,53^{d}$ & $4,40^{d}$ & \\
\hline
\end{tabular}

The average of the results in Table 2 shows that the panelists accept the combination of chicken meat and golden snail meat in terms of flavor. The average grade on treatment P0 (control) is higher than on the remaining treatments (P1, P2, P3, and P4). Build upon the analysis of variance of the nugget, there is a distinct difference of flavor $(P<0,05)$, between the control nugget and the combination nuggets. This means that the combination of golden snail and chicken meat in each treatment provided 
a distinctive impact to the nuggets produced. The results of the further SRD test indicate that treatment P0 is distinctly different from treatments $\mathrm{P} 1, \mathrm{P} 2, \mathrm{P} 3$ and $\mathrm{P} 4$. It is mainly because P0 contains $100 \%$ chicken meat, P1 consists of $75 \%$ chicken meat and $25 \%$ golden snail meat, $\mathrm{P} 2$ has each $50 \%$ of chicken meat and golden snail meal, P3 consists of $25 \%$ chicken meat and $75 \%$ golden snail meat, while $\mathrm{P} 4$ is $100 \%$ of golden snail meat.

\section{Texture}

The results of average calculation on the golden snail meat texture test are in Table 3.

Table 3. The average grade of nugget texture preference test

\begin{tabular}{|c|c|c|c|c|c|c|}
\hline \multirow{2}{*}{ Repetition } & \multicolumn{5}{|c|}{ Treatment } & \multirow{2}{*}{ Total } \\
\cline { 2 - 6 } & $\mathbf{P}_{\mathbf{0}}$ & $\mathbf{P}_{\mathbf{1}}$ & $\mathbf{P}_{\mathbf{2}}$ & $\mathbf{P}_{\mathbf{3}}$ & $\mathbf{P}_{\mathbf{4}}$ & \\
\hline $\mathbf{1}$ & 5,00 & 4,67 & 4,87 & 4,13 & 2,20 & 20,87 \\
\hline $\mathbf{2}$ & 5,07 & 4,93 & 4,67 & 4,73 & 4,60 & 24,00 \\
\hline $\mathbf{3}$ & 4,93 & 4,73 & 4,67 & 4,73 & 4,53 & 23,59 \\
\hline Total & $\mathbf{1 5 , 0 0}^{\mathbf{1 4}, 33}$ & $\mathbf{1 4 , 2 1}^{\mathbf{1 3 , 5 9}}$ & $\mathbf{1 1 , 3 3}^{\mathbf{4}} \mathbf{4 7 , 5 9}$ \\
\hline Average & $\mathbf{5 , 0 0}^{\mathbf{a}}$ & $\mathbf{4 , 7 8}^{\mathbf{b}}$ & $\mathbf{4 , 7 4}^{\mathbf{c}}$ & $\mathbf{4 , 5 3}^{\mathbf{d}}$ & $\mathbf{3 , 7 8}^{\mathbf{e}}$ & \\
\hline
\end{tabular}

Remark: different letter in the same column or row shows distinctive impact $(\mathrm{P}<0,05)$

The average results on Table 3 shows that the $\mathrm{P} 0$ treatment has the highest score in terms of preference of nugget texture compared to $\mathrm{P} 1, \mathrm{P} 2, \mathrm{P} 3$ and $\mathrm{P} 4$, which is 5,00 . The results of analysis of variance test indicate that texture gave distinct impact $(\mathrm{P}<0,05)$ on the rate of preference. Further SRD test shows that the texture on treatment P0 was distinctively different from treatments P1, P2, P3 and P4.

Treatments P1, P2, and P3 partly contained some chicken meat, while P4 was completely of golden snail meat. The quality of the combination nugget tended to be mushier. Basically, the texture of golden snail meat was coarser than chicken meat even though it had been ground or soften. More concentration of golden snail meat would cause the texture of the nugget to be more coarse and mushy. The variation of meat combinations in each formula possibly resulted in variation of texture. Golden snail is an animal-based food that contain $9,33 \%$ protein [5]., 10,30\% (Susanto 2010); 7,58\%, while chicken contains $18,2 \%$ protein [6]

The difference of protein composition in the meat was also predicted to be an important aspect for the formation of the nugget texture. The main component of the meat that influencedthe formation of texture is protein. Specifically, myosin and stroma are the two type of protein that is important for texture. According to[7] myosin is important for the formation of emulsion in the hydrophobic and lipophilic type of food product, which forms the bonding of water with fat. The emulsion is a dispersion or suspension of a liquid in another liquid, which is not soluble or miscible and antagonistic[8]. [3] claim that stroma is insoluble protein, water and salt that consist of collagen and elastin.
Odor

The average grade of hedonic quality test of the odor in each level of combination can be seen in table 4 .

Table 4.Average grade of nugget odor preference level

\begin{tabular}{|c|c|c|c|c|c|c|}
\hline \multirow{2}{*}{ Repetition } & \multicolumn{5}{|c|}{ Treatment } & \multirow{2}{*}{ Total } \\
\hline & $\mathbf{P}_{0}$ & $P_{1}$ & $\mathbf{P}_{2}$ & $\mathbf{P}_{3}$ & $\mathbf{P}_{4}$ & \\
\hline 1 & 4,80 & 4,80 & 4,93 & 4,27 & 3,87 & 22,67 \\
\hline 2 & 5,00 & 4,87 & 4,60 & 4,67 & 4,27 & 23,41 \\
\hline 3 & 4,60 & 4,60 & 4,40 & 4,40 & 4,20 & 22,20 \\
\hline Total & 14,40 & 14,27 & 13,93 & 13,34 & 12,34 & 68,28 \\
\hline Average & $4,80^{\mathrm{a}}$ & $4,76^{b}$ & $4,64^{c}$ & $4,45^{d}$ & $4,11^{\mathrm{e}}$ & \\
\hline
\end{tabular}

The average grade result (Table 4) shows that there was a difference in the acceptance of nugget odor between treatment $\mathrm{P} 0$ with treatments $\mathrm{P} 1, \mathrm{P} 2, \mathrm{P} 3$ and $\mathrm{P} 4$. The analysis of variance revealed the distinct impact $(\mathrm{P}<0,01)$ of odor preference on the combinations of golden snail and chicken in a nugget. This was due to the difference of snail meat combination percentage affecting the quality of nugget odor, which in turn impacted the preference of panelists based on the odor. Based on the odor, panelists preferred the treatment with less golden snail meat proportion. Most fishery products tend to have fishier smell compared to livestock products. It is because the water content and the number of bacteria in fishery products are quite high [9]. On further SRD test of the odor, it was shown that there was distinct difference of preference on treatment $\mathrm{P} 0$ which fully consist of chicken meat, with treatments P1, P2, P3 and P4 which had already been added with golden snail meat

\section{Fat Content}

Fat and oil are energy sources that are quite as effective as carbohydrates and protein. They are also food substances and nutritions, which are very important for human baody [8]. The fat in food fixes the form and physical structure of the food, adds additional nutrition and calory, as well as provides taste and palatability of the food. It also functions as the medium that conducts heat within the meat during frying process [13]. The average grade of fat level in the combination of golden snail and chicken meats can be seen in Table 5.

Table5.Average grade of fat level test on golden snail nugget

\begin{tabular}{|c|c|c|c|c|c|c|}
\hline \multirow{2}{*}{ Repetition } & \multicolumn{5}{|c|}{ Treatment } & \multirow{2}{*}{ Total } \\
\hline & $\mathbf{P}_{\mathbf{0}}$ & $\mathbf{P}_{1}$ & $\mathbf{P}_{2}$ & $\mathbf{P}_{3}$ & $\mathbf{P}_{4}$ & \\
\hline 1 & 3,07 & 0,92 & 2,10 & 3,32 & 2,29 & 11,70 \\
\hline 2 & 5,68 & 2,19 & 4,54 & 4,37 & 5,52 & 22,30 \\
\hline 3 & 2,34 & 2,25 & 3,09 & 3,36 & 5,20 & 16,24 \\
\hline Total & 11,09 & 5,36 & 9,73 & 11,05 & 13,01 & 50,24 \\
\hline Average & 3,70 & 1,79 & 3,24 & 3,68 & 4,34 & \\
\hline
\end{tabular}

Remark: No distinctivedifference(tn)

The result (Table 5) indicated that in average, the percentage of chicken and golden snail meats in the nugget 
had no effect on the fat level. The fat level of chicken and golden snail meat were different in each treatment. However, this had no effect on the fat level of the final nugget product.

\section{Protein Content}

Protein is an importantsubstance because it functions as the fuel for the human body. It is also the developing and controlling substance. Protein in food determines the quality of food products especially the meat-based ones [8]. The average grade of protein level test that impacted the preference of golden snail and chicken meat combination nugget are shown on Table 6 .

Table6.Average grade of protein level test in golden snail nugget

\begin{tabular}{|c|c|c|c|c|c|r|}
\hline \multirow{2}{*}{$\begin{array}{c}\text { Repetit } \\
\text { ion }\end{array}$} & \multicolumn{5}{|c|}{ Treatment } & \multirow{2}{*}{ Total } \\
\cline { 2 - 6 } & $\mathbf{P}_{\mathbf{0}}$ & $\mathbf{P}_{\mathbf{1}}$ & $\mathbf{P}_{\mathbf{2}}$ & $\mathbf{P}_{\mathbf{3}}$ & $\mathbf{P}_{\mathbf{4}}$ & \\
\hline $\mathbf{1}$ & 14,79 & 15,80 & 12,83 & 15,07 & 10,80 & 69,29 \\
\hline $\mathbf{2}$ & 15,40 & 15,31 & 13,49 & 14,99 & 14,12 & 73,31 \\
\hline $\mathbf{3}$ & 15,38 & 15,08 & 13,23 & 14,95 & 12,45 & 71,09 \\
\hline Total & $\mathbf{4 5 , 5 7}$ & $\mathbf{4 6 , 1 9}$ & $\mathbf{3 9 , 5 5}$ & $\mathbf{4 5 , 0 1}$ & $\mathbf{3 7 , 3 7}$ & $\begin{array}{r}\mathbf{2 1 3 , 6} \\
\mathbf{9}\end{array}$ \\
\hline $\begin{array}{c}\text { Averag } \\
\text { e }\end{array}$ & $\mathbf{1 5 , 1 9}^{\mathbf{a}}$ & $\mathbf{1 5 , 4 0}^{\mathbf{b}}$ & $\mathbf{1 3 , 1 8}^{\mathbf{c}}$ & $\mathbf{1 5 , 0 0}^{\mathbf{b}}$ & $\begin{array}{c}\mathbf{1 2 , 4 6} \\
\mathbf{e}\end{array}$ & \\
\hline
\end{tabular}

Remark: Different letter in the same column or row shows distinctive difference $(p<0,01)$

The result (Table 6) showed that the average grade of protein level in treatment $\mathrm{P} 1$ was higher than found on $\mathrm{P} 0$, P2, P3, and P4. The variance of analysis test shows very distinctive difference $(\mathrm{P}<0,01)$. Further SRD test indicates that treatment $\mathrm{P} 1$ is different $\mathrm{P}_{0}, \mathrm{P}_{2}, \mathrm{P}_{3}$ and $\mathrm{P}_{4}$. The difference was influenced by the fact that more golden snail meat given, the higher the protein level could be.

\section{CONCLUSIONS}

Based on the result of this research, it was concluded that the best combination of chicken and golden snail meat nugget in terms of protein level and the most preferable was shown in treatment P1 (75\% chicken meat $+25 \%$ golden snail meat), in which the points for color, taste, texture, and odor are the highest, while the fat has no distinctive influence.

\section{ACKNOWLEDGMENT}

The authors would like to express their sincere thanks to the Research and Dedication Board to the Khairun University Community and the Faculty of Agriculture, Khairun University for financial support. They also greatly appreciated the assistance provided by the Food and Nutrition Chemistry Laboratory, Faculty of Agricultural Product Technology Bogor IPB for all facilities provided during the research

\section{REFERENCES}

[1] Tanoto, E. 1994.Pembuatan Fish Nugget darilkan Tenggiri .Skripsi .Jurusan Teknologi Pangan dan Gizi.Fakultas Teknologi Pertanian. Bogor :Institut Pertanian Bogor.

[2] Irianto, H. E Giyatmi, S. 2002. Teknologi Pengelolahan Hasil Perairan. Depertemen Pendidikan Nasional, Universitas Terbuka. Jakarta

[3] Gaspers, V. 1991. Metode Perancangan Percobaan. CV. Armico, Bandung

[4] Nurjannah, Subari Yanto and Patang, 2017. Pemanfaatan Keong Mas (Pomacea Canaliculata L) Dan Limbah Cangkang Rajungan (Portunus Pelagicus) Menjadi Pakan Ternak Untuk Meningkatkan Produksi Telur Itik. Jurnal Pendidikan Teknologi Pertanian, Vol. 3 (2017) : 137-147

[5] Persagi.2009. Tabel Komposisi pangan Indonesia. Jakarta. PT Elex Media Komputindo.

[6] Rinaldi, D. 1992. Penggunaan Metode Triangle dan Concentration Count dalam Penelitian Sebaran dan Populasi Hylobatidae (Hylobatidae). Media Koservasi 1:9-21

[7] Winarno, F. G. 2008. Kimia pangan dan gizi. PT Gramedia Pustaka Utama, Jakarta

[8] Muchtadi TR. 1989. Petunjuk Laboratorium Teknologo Proses Penggolahan Pangan. Depertemen Pendidikan Dan Kebudayaan Direktorat Jendral Perguruan Tinggi. Pusat antar Universitas Pangan dan Gizi.IPB. Bogor.

[9] Keteren, S. 1986. Pengantar Teknologi Lemak dan Minyak Panagan. UI Press: Jakarta 